\title{
Environmental Ethics through Value-Based Education
}

\author{
Ravichandran Moorthy ${ }^{1}$, Gabriel Tyoyila Akwen ${ }^{2}$ \\ 1. Associate Professor, Universiti Kebangsaan Malaysia, Asian Bioethics Association, Email: drravi@ukm.edu.my \\ 2. Department of Political Science, Federal University Gashua, Yobe, Nigeria \\ Email: akwengab123@gmail.com, akwengabriel@,fugashua.edu.ng
}

DOI: https://doi.org/10.3329/bioethics.v11i2.49257

\begin{abstract}
Environmental ethics is the subject in philosophy that examines the moral relationship of human beings to the environment and its non-human species. It concerns human's ethical relationship with the natural environment. The central question concerning environmental ethics is essentially - what is human being's moral obligation concerning the natural environment? The paper will firstly provide a review of the ethical relations of humans and the environment, secondly examine how value-based education can assist in inculcating environmental ethics among learners.
\end{abstract}

Keywords: Environment ethics, Value-based educations, Values, Ethics, Moral obligations

Introduction: Mother earth is in great perils. Human activities and the demand for resources have created enormous pressure and stress on the sustainability of Earth. Resource depletion and environmental devastation have plagued the world in the last several decades, creating havoc to the environment and the life of species inhabiting it, which includes the humans. Human neglect, due to over development, has created many environmental issues, such as excessive pollution in land, water and air, overpopulation, poor management of industrial and household waste, climate change and global warming, deforestation and others, have impacted mother Earth severely. These impacts are already clearly visible - the impacts on human health, the melting of the ice-cap and rise in sea levels, extinction of certain species, irreversible pollution of the water sources, unhealthy air levels and many more. Despite being the most intelligent species, humans, due to their greed and consumption patterns, have willingly allowed for the ruin of the environment. In the past decade many initiatives are being carried out at all levels of society to create environmental awareness and invoke actions to mitigate environmental degradations and climate change issues. The authors posit that mitigation efforts should start in the school systems.

Besides imparting knowledge and skills, values education should be imparted with greater emphasis. Values, norms and principles of nature should also be taught at an early age, so that children start to appreciate and value nature and the environment since childhood. Only through the inculcation of ethics for the love, preservation and protection of the environment that long term solutions have be envisioned. While some of the damages to the environment are natural, a host of others are manmade. "Man with his domestic 
animals his domestic animals, cultivation and fire can induce changes, similar to those produced by a reduction in the long term average precipitation, in a very much shorter time" 1. The environment could be saved from both natural and human disasters through environmental ethics value-based education. This would enhance man's understanding, attitudes, and skills on how to relate in the environment. Besides, disaster mitigation strategies could be acquired through such education. In most cases, fields trips that are environmental based have proven to change the students' perception of the environment.

\section{Importance of Environmental Ethics:}

Ethics are shared values of the society that are not static, they can be changed or revised, due to prevailing circumstances in the society. Other features of ethics include belief and attitudes. Environmental ethics is a body of knowledge that deals with an understanding of the moral association between man and the natural environment, including the nonhuman creatures that inhabit and constitute the environment ${ }^{2}$. Environmental ethics encompasses developing a fitting grasp of the human-nature association, noting the goods and principles that emerge from the relationship, determining the rules that those goods and principles substantiate, and employing those norms to make regulations on environmental concerns and interactions ${ }^{3}$.

Studies on environmental ethics began during the post-modern thinking era. This was after the technological civilization (increase use of pesticides, deforestation and industry) brought about a new culture that sees human beings as the master of the environment ${ }^{4,5}$.
The new culture came with problems like air and water pollution, the exhaustion of environmental resources, depletion of the ozone layer, forfeiture of biodiversity, destruction of ecosystems, and worldwide climate change ${ }^{6}$.The aforementioned constitute ethical discussions and subsequently influence the human ability to solve environmental problems.

Although there are rising concerns about environmental issues in nearly all aspects of human lives, the ethical environmental values and norm have not been very well emphasized in policies relating to the environment. Fundamental ethical questions should be openly debated, to provide the required clarity of thought on the goals the policy expect to achieve. "Should we only protect the environment to the extent that we have an interest in it? What is it that is worth protecting: species, individuals, ecosystems? What does the notion of sustainability means ${ }^{7}$ ?". Thinking about these questions are essential as it allows the policymaker to reflect on the ethical principles that these policies will anchor on. Yet, in reality, maybe due to ethical ignorance, "questions like these often remained unanswered and sometimes even unasked, in the formulation and implementation of environmental policies and actions" ${ }^{\prime 8}$.It is by asking and answering the above-raised questions that the relevance of environmental ethics would be felt.

An education that is environmental ethics based would assist man to delineate his moral and ethical responsibilities to the environment, even in the face of a threat to man's survival. For instance, in developing countries, people living in the rural areas 
depend on firewood for their cooking, but cutting down of trees for this purpose is disastrous to the environment from the perspective of those living in developed societies. Actions such as this and many more that are motivated by survival instincts are morally rejected in some quarters because of their negative impact on the environment. Through the discipline of environmental ethics, man has come to strike a balance on how to utilize environmental resources without causing much harm. This is done through the teaching of ethical decisions, for example, the poor in most rural poor communities are encouraged to plant two trees when they cut one down. Environmental ethics is useful for pointing out that if conscious efforts are not taken the next generations will not afford to meet their needs from the environment. It further advocates for the avoidance of bad environmental behaviour' .

On the part of organisations, environmental ethics is an essential inner resource that permits firms to utilize a value-creating approach for augmenting environmental performance. In this context, environmental performance denotes an organization's behaviour concerning the natural environment. This has to do with how the organization taps accessible resources with a resilient obligation to check activities that can harm the environment. Through environmental ethics, many firms have developed the natural inclination to build synergy among their internal resources to improve their environmental performance as a strategy of outclassing their competitors ${ }^{10}$. To this end, business environmental ethics of organizations stimulate proactive environmental activities and improves environmental performance. This is why environmental education (training) to employees has become a sine qua non and more relevant ${ }^{11}$ because of its ability to boost the organization's environmental performance and competitiveness. Employee's environmental morals, motivations and behaviour in terms of knowledge and utilization of ideas in line with green products and resources recycling ${ }^{12}$ are important components that enhance environmental performance and competitiveness of firms.

In another dimension, compared to a few decades past where only a handful of people realized that man's activities were altering the world's environment, with the emergence of environmental ethics, more people are informed about how human impunity actions are rapidly destroying the global environment. Therefore, new information and improved understanding now characterize the human relationship with the environment. In this regards human beings have realized that they have a moral duty to leave the environment in good condition for the future generation. More so, that we are not at liberty to exploit environmental resources to the level of exhaustion. Most importantly that other species have rights to co-live with human beings in the environment as well ${ }^{13}$.This new knowledge demonstrates the relevance and dire need for environmental ethics.

With environmental ethics culture, Humancentered standpoints can be changed into eco-centred views and human perceptions about the environment and environmental 
principles can be transformed positively. Environmental ethics education can reveal the path and strategies of inculcating positive environmental values in students.

Particularly at the universities as important places in people's scientific and social development, young people taking both vocational and environmental ethics education will not be the source of environmental problems but part of the solution when they begin their professional career. In this theoretical study, the importance of environmental ethics education for university students will be emphasized ${ }^{14}$.

Environmental ethics plays an important role in man's quest to preserve the earth and manage the natural resources to meet the needs of the geometric increasing human population. This cannot be achieved with man's inadequate perception of environmental ethics. Through education in environmental ethics, man has come to understand that there many environmental ethics that we need to practice as we carry out our day-to-day activities to maintain the sustainability of the.

\section{Environmental Ethics Principles:} Generally, the debate on environmental ethics falls into four wide-ranging aspects; "firstly it reflects on human beings' ethical relationship with the natural environment; secondly, it concerns human beings' responsibility in safeguarding and preserving the natural environment; thirdly it concerns human beings' in providing leadership in safeguarding and preserving the natural environment and fourthly it concerns human beings' in ensuring earth's resources remains adequate for future generations" ${ }^{15}$. These dimensions need to be guided by environmental ethics principles for success to be achieved. There are numerous principles to establish how humans should treasure the environment. The vastness of the field of environmental ethics makes it challenging for one principle to be applied. Several theories have been propounded since the inception of the discipline of environmental ethics, and they have highlighted countless principles of environmental ethics. More so, due to differences in environmental problems and human needs of different societies, there are no universally accepted principles of environmental ethics. Be that as it may, some of the principles that are predominantly found in the existing theories are discussed below.

Anthropocentrism is one of the principles of environmental ethics. Etymologically, the concept of anthropocentrism is derived from a combination of two Greek wordś " $\alpha v \theta \rho \omega \pi$ os (Anthropos, or human being) and

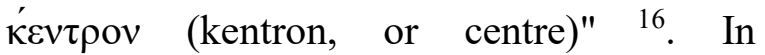
environmental ethics, anthropocentrism connotes "the belief that value is humancentred and that all other beings are means to human ends" ${ }^{17}$. By this, it means that only human beings are worthy of moral contemplations. $^{18} \quad$ The word anthropocentrism is a global held perspective that accord privileges to the improvement of man's welfare at the detriment of other aspirations. Anthropocentrism could be viewed as the love of one's species, and, secondly, as intolerance for other species ${ }^{19}$. This principle contents that man is the most 
essential being, all other living creatures are just fixtures designed to support man's survival and development. There are two strands of anthropocentrism-the weak and strong anthropocentrism. Whereas weak anthropocentrism thinks that human beings are the hub because it is only via the human standpoint that environmental conditions are understood. Strong anthropocentrism, on the other hand, believes that human beings are the focus because they justly deserve to be there ${ }^{20}$.

Non-anthropocentrism is another known principles of environmental ethic. In contrast to anthropocentrism, the principle of nonanthropocentrism offers value to every object, every animal dwelling in an environment. This principle believes in everything that sustains itself in nature. From the lens of Non-anthropocentrism, the world is not seen based on its utility but its intrinsic worth. Hence, the stance that man is not superior to members of all species. ${ }^{21}$ This principle believes that the non-human world also possesses an essential value in itself and broadens moral standing to non-human species. Among the adherents of this principle, some expand morality only to species that can react to pleasure and pain, for instance, humans and animals, others, to all living beings, plants and trees inclusive, and some to the degree of including the land, rocks, soil, ecosystem, etc ${ }^{22}$. The nonanthropocentrism principle is perceived as an abstraction given the level of urbanization and technological advancements that characterized the contemporary world ${ }^{23}$. There are many variants of nonanthropocentrism, sometimes they are treated as separate principles of environmental ethics. While at some instance the concept "ecocentrism" is counted as a principle of environmental ethics, in this context it is seen as one variety of non-anthropocentric principle. Others include hierarchical biocentrism, psychocentrism, and egalitarian biocentrism $^{24}$.

Widyaningtyas, et $\mathrm{al}^{25}$ identify three principles of environmental ethics "(1) Compassion for nature bearing, (2) respect for nature bearing, and (3) life in harmony with nature bearing", which they posit are derived from biocentric and eco-centricity theory. From their first principle it can be deduced that as humans progressively love and care for the environment, a mutual and strong relationship would be established between individuals and nature. To this extent, nature is viewed to be alive in a physical, spiritual and mental sense. The second principle is founded on the theory ecological community, which asserts that the environment is a moral community and humans as community members have a moral responsibility to respect other members of the community. The third principle stresses that the quality of a good life is not determined by facilities, wealth or material values. Life in harmony with nature bearing as a principle states that Human beings need to see themselves as a part of nature, therefore, should make use of nature appropriately. This can be achieved through obedience to natural law, which entails moderate utilization of nature and avoidance of overexploitation ${ }^{26}$.

From the African standpoint, Ibanga ${ }^{27}$ pinpoints five principles of environmental ethics, which are taken from the broad corpus of African environmental ethics. One of the 
principles is that of accommodation. It portrays that nonhuman presence and care for future generation should be contemplated and accommodated in humans' day-to-day resolves and dealings. Next is the Principle of Gratitude. Under this principle, man is expected to act towards the environment in such a manner that reflects appreciation towards other species. Because even the nonhumans contribute and support man's existence in the environment. The third is the principle of restoration. It admonishes human beings to always restore to nature the loss they have caused it. For instance, re-planting two trees after one is deliberately cut down. The succeeding is the principle of control. Here man is encouraged to act in a fashion that he would be able to control and prevent his actions from creating too many undesirable externalities. The last is the principle of necessity. Man is expected to act only on choices and actions that are extremely necessary.

All the above-discussed principles of environmental ethics are precepts proposed to guide peoples' actions in the environment. Most of the principles call for control and caution to man's decisions and actions, so that his lifestyle and dealings would prevent depletion of resources and reduce damages that his lifestyle can cause other beings and their communities. Put differently, these principles serve as a framework to foresee before acting.

Value-based Education: What is valuebased education? Value-based education is a philosophy and approach to education that emphasizes the inculcation of principles, values and ethics to the learners. It is an innovative way of thinking about education, where learners are introduced to values holistically by assimilating these values as principles that will guide behavior and actions $^{28}$. The next question is why there is a need for value-based education? The rat-race to acquire for academic and professional qualifications have undoubtedly pushed value education on the sideline. Material success, competitions and consumptions have become the new-age mantras in society - contributing the degradation of human values, their behaviours and negative impacts to the environment. Therefore, to address these harms, the authors believe that the education philosophy and education systems requires a thorough reexamining and revision. A more robust and significant value-based education curriculum need to incorporate into the school syllabus that will invoke the desired human values and ethics. "Philosophers, educationists, and other stakeholders can be the catalyst to create awareness among the public and policy makers on the necessity to relook and revamp the education system, across the board" ${ }^{29}$.

What are desired values in value-based education? There many moral and ethical values and norms that regulates human behaviours in societies. The values are cultural and society-specific, one society may place a greater importance of a specific set of values compared to another society. Societies may have different levels priority and acceptance of values and norms in society. However, the universal values such as respect, tolerance, peace, care, compassion and love manifest in all societies. Through value-based education, learners have the 
opportunity to learn, deliberate and reflect their actions based on these values. The school syllabus of some countries have incorporated Moral or Civic classes as part of their curriculum, where values are specifically taught. Nonetheless, value education may be carried out in any type of lessons, but the values can be drawn out in the activities. For instance, "in a geography lesson regarding water resources, learners can be exposed to the principle of water for all (water equity or sharing), the right for access to clean water (human rights), as well as responsibility to use water in a sustainable way (environmental ethics)"..$^{30}$ Through this geography lesson, learners have the opportunity to internalize the values of sharing, respect for the rights of all, and responsibility to the environment. Through these activities, teachers or instructors can initiate discussion in class and encourage the learners to reflect of these values. Studies show that value-based education tend to produce learners with more self-confidence and take greater responsibility for their actions and behaviours.

Subsequently, when learners start thinking about these values and reflect it within their lives, it becomes a normative set of values for that individual. This allow them to be more reflective and self-aware, with regards to their actions and behaviours. When learners start to internalize and model the values in their lives, they become ethically intelligent. It refers to the consequence of thought process on an ethical vocabulary, that may encompass value-loaded words such as love, compassion, peace, respect, justice, fairness etc. When learners start thinking about the gist of these vocabulary, and incorporate those expressions into their lives, they became ethically intelligent. Weinstein ${ }^{31}$ asserts that individually who are ethically intelligent know how to employ this awareness the immediately. Nevertheless, being ethically intelligent is not only about knowing what is right, but having the resolve to do what is deemed right. Ethical intelligence is most valuable, and it manifest through five principles - do no harm, make things better, respect others, be fair, and be loving. These principles are the buildingblock of communities, societies and nations, it binds individuals together, as persons of faith and in all relationship individuals have or are likely to have $\mathrm{e}^{32}$.

The authors believe that environmental ethics and its awareness can be inculcate more efficiently through value-based curriculum and teaching. As explained in the previous paragraphs, values, norms and ethics that allows for the safeguard and appreciation of the environment should inculcate early in the schooling process. The experiential learning that takes place in value-based systems will improve learners' relational trust and become more engaged in value-based environmental discourses. Individuals need to feel responsible and empowered to be a guardian for the environment. They will feel compelled, not only to constantly acts in an sustainable way, but also have the moral standing to speak up against actions by others that are environmentally unsustainable.

Conclusion: The importance of value-based education in the school curriculums have been largely neglected or even ignored. Moral and civic classes in schools are usually 
non-exam lessons, and are often regarded not important by the schools and parents. The school systems and even the parents often place great emphasis on subjects and exams that will secure their children jobs and further educational opportunities. This is an incorrect postulation, while job seeking skills and knowledge are important, value and ethics education is crucial for characterbuilding of individuals. For example, Indian thinkers claimed that 'the end of education is character', which denotes to the mental and moral qualities distinctive to an individual ${ }^{33}$. For Mahatma Gandhi, education is the development of human personality, which reveals in the body, mind, heart and spirit of humans. Through education, the spiritual, intellectual and physical strength of the individual is aroused. Subsequently, it also arouses the notions of sympathy, fellowship and deep feelings of love. "It also nurtures conflict resolution behavior among individuals - that is to manage differences through dialogue, tolerance, friendship, reconciliation and confident building among individuals" ${ }^{34}$. Therefore, the purpose of education is to produce individuals who endowed with values and norms, and understand one's responsibilities in the world in which one lives ${ }^{35}$.

\section{References:}

1. Campbell, A. \& Graham, C. The impact of man on the environment of Botswana. Botswana Notes and Records 1971: 91-110.

2. Akpan, B. S., \& Leonard, N. Environmental ethics: from philosophy to movement.

Bulletin Social-Economic and Humanitarian Research, 2018; (2). https://cyberleninka.ru article/n/environmental-ethics-fromphilosophy-to-movement [14 August 2020].

3. Sandler, R. L. "Environmental virtue ethics. International Encyclopedia of Ethics. 2013.
4. Pai, T.Y., Wang, S.C., Lo, H.M., Chen, L., Wan, T.J., Lin, M.R., Lin, C.Y., Yang, P.Y., Lai, W.J., Wang, Y. H. \& Lu, T.H. "A simulation of sewer bio deterioration by analysis of different Environmental ethics and Literacy 875 components with a model approach", International Bio deterioration and Biodegradation. 2017; (125): 37-44. https://doi.org /10.1016/j.ibiod.2017.08.003 [14 August 2020].

5. Liu, Q., Cheng, Z., \& Chen, M. Effects of environmental education on environmental ethics and literacy based on virtual reality technology. The Electronic Library. 2019; 37(5) $860-877$

6. Environmental Ethics and Principles of Implementation. 2020. https://www.academia./ 38498608/ EnvironmentalEthicsandPrincipleofImpleme ntation [15 August 2020]

7. Ten Have, H.A.M.J. Environmental Ethics and International Policy. 1st Edn, UNESCO: Paris, 2006

8. Ibid

9. Temel, S. Prospective teachers' understanding of environmental ethics approach: A qualitative study. In SHS Web of Conferences. 2019; (66): 01-10.

10. Singh, S. K., Chen, J., Del Giudice, M., \& ElKassar, A. N. Environmental ethics, environmental performance, and competitive advantage: role of environmental training. Technological Forecasting and Social Change, 2019; (146): 203-211.

11. Singh, S.K. \& El-Kassar, A.N. Role of big data analytics in developing sustainable capabilities. J. Clean. Prod, 2019; (213): 1264-1273.

12. Sarkis, J. The role of employees' leadership perceptions, values, and motivation in employees' provenvironmental behaviors. J. Clean. Prod. 2018; (196): 576-587.

13. Verma, A. K. Environmental ethics: Need to rethink. International Journal on Environmental Sciences. 2017; 8(1): 7-9.

14. Karataş A. The importance of Environmental Ethics Education at Universities. 8th International Technology, Education and 
Development Conference Valencia, Spain. 10-12 March, 2014. Publisher: IATED; 2014.

15. Moorthy, R. \& Jeyabalan, G. Environmental Ethics in River Water Management American Journal of Environmental Sciences 2011; 7(4): 370-376

16. Kopnina, H. "Anthropocentrism and PostHumanism." The International Encyclopedia of Anthropology 2018: 1-8.

17. Kopnina, H, et al. Anthropocentrism: More than just a misunderstood problem. Journal of Agricultural and Environmental Ethics. 2018; 31(1): 109-127.

18. Callicott, J. B. "Conservation Values and Ethics." In Principles of Conservation Biology, edited by Martha J. Groom, Gary K. Meffe, \& C. Ronald Carroll, 111-35. Sunderland, MA:Sinauer; 2006.

19. Hayward, T. Anthropocentrism: A Misunderstood Problem. Environmental Values. 1997; 6(1): 49-63.

20. Kukreja, R. What are Environmental Ethics? 2020 https://www.conserve-energy-future .com/environ- mental-ethics.php. [14 August 2020]

21. Jagat, P. "Sterba on Reconciling Anthropocentric with Non-Anthropocentric Ethics", Indian Philosophical Quarterly, 2003; 33(3): 443.

22. Carrie, W. The Role of Philosophy in Environmental Debates. http://www.helium. com/items/1436902-ethics-environmental [19 August 2020].

23. Weston, A. Non-anthropocentrism in a thoroughly Anthropocentrized world. The Trumpeter 1991; 8 (3):1-9

24. Kortetmäki, T. Anthropocentrism versus ecocentrism revisited: Theoretical confusions and practical conclusions. SATS. 2013; 14 (1) 21-37.

25. Widyaningtyas, P. \& Else Liliani. Principles of Environmental Ethics in Indonesian Newspaper Short Stories: An Ecocriticism Study. 1st International Conference on Language, Literature, and Arts Education (ICLLAE 2019). Atlantis Press, 2020.

26. Ibid
27. Ibanga, D. Concept, Principles and Research Methods of African Environmental Ethics. 2018; 11(7): 123-142

28. Moorthy, R. \& Sivapalan, S. Some ethical thoughts from the Indian traditions. Eubios, J. Asian, Int. Bioethics. 2010; (20): 180-183.

29. Moorthy, R. 2019. Value-Based Education to Overcome Hatred \& Divide. In Macer, D.R.J (ed). Legacies of Love, Peace and Hope: How Education can overcome Hatred and Divide. Christchurch, N.Z.: Eubios Ethics Institute. pp.87-92

30. Ibid

31. Weinstein, B. 2011. Ethical Intelligence: Five Principles for Untangling Your Toughest Problems at Work and Beyond. California: New World Library.

32. Ibid

33. Chandrasekar, V. Conflict Resolution through Value-Based Education and Its Impact: The Indian Model. In Moorthy, R. and Panneerselvam, S. (eds.). Conflict Resolution: Perspectives from Indian Philosophy and Traditions. UKM Press: Bangi, 2018.

34. Moorthy, R. Indian Civilization, Philosophy and Conflict Resolutions. In Moorthy, R. and Panneerselvam, S. (eds.). Conflict Resolution: Perspectives from Indian Philosophy and Traditions. UKM Press: Bangi, 2018.

35. Devi, A. H. 'Gandhi's concept of education and its ethical perspectives for the development of peace.' 2019. https://www.mkgandhi.org/articles/g_edu.ht $\underline{\mathrm{m}}$ [1 August 2019].

Author Contributions: The $1^{\text {st }}$ author Ravichandran Moorthy conceived the idea, did the literature review and wrote the manuscript. The $2^{\text {nd }}$ author Gabriel Tyoyila Akwen guided the conception of the idea, the manuscript writing, and checked the manuscript meticulously.

Conflict of interests: The authors declare that there is no conflict of interest in this study 